\title{
COMPARISON OF MICROSTRUCTURES AND OXIDATION \\ BEHAVIORS OF YTRIA AND MAGNESIA STABILIZED ZIRCONIA THERMAL BARRIER COATINGS (TBC)
}

\author{
PRIMERJAVA MED MIKROSTRUKTURAMI IN OKSIDACIJSKIMI \\ OBNAŠANJI Z ITRIJEM IN MAGNEZIJEM STABILIZIRANIH \\ CIRKONSKIH PREVLEK ZA TERMIČNO ZAŠČITO (TBC)
}

\author{
Kadir Mert Doleker ${ }^{1}$, Yasin Ozgurluk ${ }^{1}$, Dervis Ozkan² ${ }^{2}$ Nihal Mesekiran ${ }^{1}$, \\ Abdulah Cahit Karaoglanli ${ }^{1}$ \\ ${ }^{1}$ Bartin University, Department of Metallurgical and Materials Engineering, 74110 Bartin, Turkey \\ ${ }^{2}$ Bartin University, Department of Mechanical Engineering, 74110 Bartin, Turkey \\ kmdoleker@bartin.edu.tr \\ Prejem rokopisa - received: 2017-09-18; sprejem za objavo - accepted for publication: 2017-11-14
}

doi: $10.17222 /$ mit.2017.150

\begin{abstract}
Thermal barrier coatings (TBCs) provide protection to minimize aggressive environmental conditions such as oxidation, corrosion and thermal shocks occurring at high temperatures. In this study, a CoNiCrAlY metallic-bond coat was deposited on an Inconel 718 superalloy substrate with a thickness about $100 \mu \mathrm{m}$ using the atmospheric-plasma-spray (APS) method. The production of TBCs was accomplished by depositing $\mathrm{Y}_{2} \mathrm{O}_{3}$ partially stabilized zirconia (YSZ) and MgO-stabilized zirconia (MSZ) as two different ceramic top-coating materials, having the total thickness of $300 \mu \mathrm{m}$. The specimens were subjected to a metallographic investigation before the oxidation tests; their surface roughness, porosity, hardness and microstructura properties were investigated and then compared with the results obtained after the oxidation tests. The TBC systems were subjected to isothermal-oxidation tests at $900{ }^{\circ} \mathrm{C}$ and $1000{ }^{\circ} \mathrm{C}$ for $(8,24,50$ and 100) $\mathrm{h}$. After the oxidation tests, XRD, SEM and EDX elemental analyses were carried out and the changes in the thickness and structure of the thermally grown oxide (TGO) layer were investigated. A remarkable change occurred between the top and the bond coat in the TBC systems depending on the increasing time and temperature. The TGO layer thickness showed an increase. At the interface, $\mathrm{Al}_{2} \mathrm{O}_{3}$ and other mixed-oxide layers occurred. Before and after the oxidation, XRD analyses showed that YSZ had a tetragonal phase and a bit of a monoclinic phase. The MSZ coating included tetragonal, monoclinic and cubic phases at the end of the oxidation. This phase transformation causes a large volume increase in an MSZ lattice. Due to this volume increase, MSZ coatings suffer more damage than YSZ coatings.
\end{abstract}

Keywords: atmospheric plasma spray, thermal barrier coatings, oxidation, $\mathrm{ZrO}_{2}-\mathrm{Y}_{2} \mathrm{O}_{3}, \mathrm{ZrO}_{2}-\mathrm{MgO}$

Prevleke kot termične prepreke (TBCs; angl.: Thermal Barrier Coatings) zagotavljajo zaščito pred agresivnim okoljem in zmanjšajo oksidacijo, korozijo in termični šok zaradi obratovanja pri visokih temperaturah. V študiji avtorji obravnavajo kovinsko difuzijsko vezano prevleko na osnovi CoNiCrAlY, nanešeno na podlago iz superzlitine Inconel 718 debeline okoli 100 $\mu \mathrm{m}$, ki je izdelana z metodo atmosferskega plazemskega naprševanja (APS; angl: Atmospheric Plasma Spray). Dve različni keramični TBCs, celotnih debelin $300 \mu \mathrm{m}$, so izdelali $\mathrm{z}$ nanašanjem z $\mathrm{Y}_{2} \mathrm{O}_{3}$ delno stabiliziranega cirkonijevega oksida $\mathrm{ZrO}_{2}$ (YSZ, angl.: Yttria partially Stabilized Zirconia) in z MgO-stabiliziranega cirkonijevega oksida (MSZ; Magnesia Stabilized Zirconia). Na izdelanih vzorcih so izvedli primerjalne metalografske preiskave, pred in po oksidacijskih testih, in sicer: hrapavost površine, poroznost, trdoto in mikrostrukturne lastnosti. TBC-sistema sta bila izpostavljena testom izotermalne oksidacije pri $900{ }^{\circ} \mathrm{C}$ in $1000^{\circ} \mathrm{C}$ za $(8,24,50$ in 100) ur. Po oksidacijskih testih so izvedli XRD, SEM, EDX-elementne analize, kakor tudi ugotovili spremembe debeline in strukture termično zrasle oksidne plasti (TGO; angl.: Thermally Grown Oxide). Avtorji so ugotovili znatne spremembe, ki so nastale na vrhu prevlek in v prevlekah glede na naraščajoči čas in temperaturo oksidacijskega testa. Debelina TGO- plasti se je povečevala na meji med $\mathrm{Al}_{2} \mathrm{O}_{3}$ in drugimi med oksidacijo nastalimi mešanimi oksidi. XRD-analize, pred in po oksidaciji, so pokazale, da vsebuje YSZ pretežno tetragonalno in malo monoklinske faze. MSZ pa vsebuje tetragonalno, monoklinsko in na koncu oksidacije kubično fazo. Ta fazna transformacija povzroča velike volumske spremembe v MSZ-mreži. Zaradi povečanja volumna so poškodbe pri enakih pogojih oksidacije večje pri MSZ-prevlekah kot pri YSZ-prevlekah.

Ključne besede: atmosfersko plazemsko naprševanje, prevleke za termično zaščito, oksidacija, $\mathrm{ZrO}_{2}-\mathrm{Y}_{2} \mathrm{O}_{3}, \mathrm{ZrO}_{2}-\mathrm{MgO}$

\section{INTRODUCTION}

Thermal-barrier-coating systems (TBCs) are generally used to provide thermal insulation for aircraft engines and stationary, hot gas-turbine components. ${ }^{1-3}$ The TBC systems used at high temperatures increase the efficiency and life time of engines and turbine components. ${ }^{4-7}$ The TBCs consist of a heat-resistant ceramic top coating, a metallic bond coat on superalloy substrates and a thermally grown oxide (TGO) layer formed at the interface of the metallic bond and ceramic top coating during a high-temperature oxidation. ${ }^{3,8-10}$ The bond coat generally protects superalloy substrates from excessive oxidation and corrosion and also provides an adhesive surface for the ceramic top coat in these systems. The ceramic top coat is mainly used for thermal insulation and some additional corrosion and oxidation resistance in TBC systems. For the deposition of TBCs, the APS 
technique is generally used due to the need for high melting temperatures. Since the APS coatings exhibit a lamellar microstructure, lower thermal conductivities are obtained compared to the other methods. ${ }^{411-13}$

In the production of TBCs, nickel-based superalloys are used as the substrate material, MCrAlY powders are chosen as metallic bond coats and stabilized zirconia is widely used as the top-coat material..$^{9,14,15} \mathrm{ZrO}_{2}$ has a monoclinic phase at room temperature and tetragonal and cubic structures at high temperature. The monoclinic tetragonal transition occurs with a high volume change. Thus, stabilizing oxides such as MgO (15-24\%) and $\mathrm{Y}_{2} \mathrm{O}_{3}(7-8 \%)$ are added to zirconia to overcome this problem. YSZ is a conventional state-of-the-art material for TBC systems due to its high fracture toughness, low thermal conductivity and high thermal-expansion coefficient compatible with that of the substrate. While YSZ with a fully stable tetragonal phase preserves its stability in a range from room temperature to about $1200{ }^{\circ} \mathrm{C}, \mathrm{MSZ}$ has a partially stable tetragonal phase in a range from room temperature to about $950{ }^{\circ} \mathrm{C} . .^{12,16} \mathrm{In}$ addittion, at elevated temperatures up to around $1250{ }^{\circ} \mathrm{C}$, it will decompose into a monoclinic system and $\mathrm{MgO}$. However, MSZ is cheaper than YSZ. In jet engines, exhaust-nozzle materials running at low temperatures can be coated with MSZ to provide thermal insulation. ${ }^{17}$ Regarding the thermal properties of both TBC systems, the thermal conductivity of MSZ is relatively lower than that of YSZ. On the other hand, the thermal-expansion coefficient of MSZ is close to that of YSZ. ${ }^{18}$

The aim of this paper is to investigate the oxidation behavior and make a comparison between YSZ and MSZ coatings. This will enable us to understand the oxidation mechanism of TBC systems. A cross-sectional microstructural analysis was carried out to examine the oxidation-product formation and degradation mechanisms. Significant results of our study are presented in this paper.

\section{MATERIALS AND METHODS}

\subsection{Characterization}

The cross-sectional microstructures of TBCs were evaluated using a scanning electron microscope (SEM, Tescan, MAIA3 XMU, Czech Republic) equipped with energy dispersive spectroscopy (EDS, Oxford Xmax 50, UK). TBCs were subjected to an X-ray diffraction (Rigaku Dmax $2200 \mathrm{PC}, \mathrm{Cu}-K_{\alpha}$ radiation, Japan) analysis from their top surfaces to observe the phase changes indicated by the results obtained before and after the oxidation.

\subsection{Preparation of TBC samples}

In this study, the Inconel 718 superalloy with a 25.4-mm diameter and 4-mm thickness was selected as the substrate material for its high strength and creep resistance. This material is commonly used for the applications that require high mechanical capabilities. Sample surfaces were completely grit blasted before the spraying process. The CoNiCrAlY (Co-32Ni-21Cr-8Al0.5Y, Sulzer Metco, Amdry 9951, 5.5-38 $\mu \mathrm{m}$ ) powder with a thickness of approximately $100 \mu \mathrm{m}$ was sprayed on Inconel 718 as the bond-coat layer using the APS technique. After the deposition of the bond coat, $\mathrm{ZrO}_{2}+8 \%$ $\mathrm{Y}_{2} \mathrm{O}_{3}(\mathrm{GTV},-45+20 \mu \mathrm{m})$ and $\mathrm{ZrO}_{2}-24 \% \mathrm{MgO}$ (Metco $210,-90+11 \mu \mathrm{m})$ powders were sprayed on the CoNiCrAlY bond coat as the top coating layer with a $300-\mu \mathrm{m}$ thickness using the APS technique.

\subsection{Microstructural characterization of the powder ma- terial}

The characterization of the powder materials was carried out with SEM using a 600× magnification to analyze their shapes and sizes. After the SEM investiga-
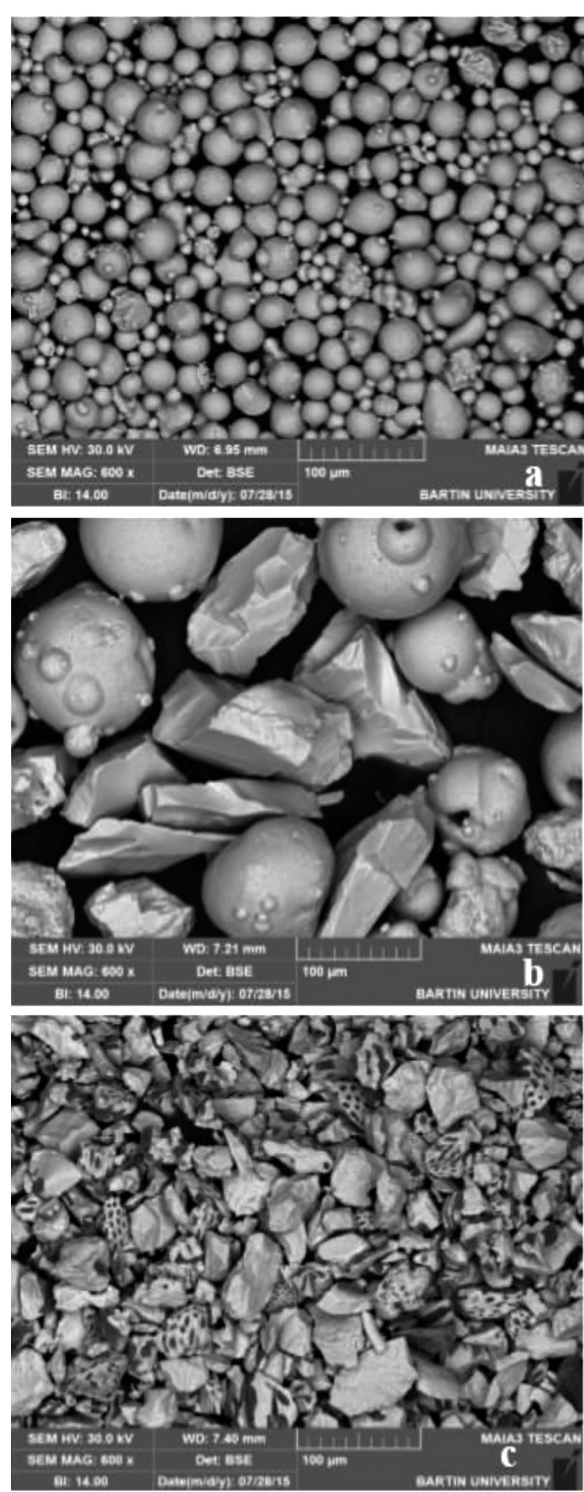

Figure 1: SEM images of coating powders: a) CoNiCrAlY, b) $\mathrm{ZrO}_{2}-\% 8 \mathrm{Y}_{2} \mathrm{O}_{3}$, c) $\mathrm{ZrO}_{2}-\mathrm{MgO}$ 
tions, powder-particle sizes were observed. Figure 1 presents SEM images of coating powders. Figure 1a shows the metallic bond-coat powder with a large majority of spheroidal granules.

In Figure 1b, the YSZ powder is a mixture of spheroidal granules and planar-angular particles when compared with the CoNiCrAlY bond-coat powder particles. The morphology of the MSZ powder particles is given in Figure 1c. These particles have a more angular structure compared to the YSZ and bond-coat powder particles.

\subsection{Chemical composition of the substrate material}

The chemical composition of the commercially available Inconel 718 superalloy is given in Table 1. As seen from this table, the high corrosion resistance of this material can be attributed to its high $\mathrm{Ni}$ and $\mathrm{Cr}$ contents.

Table 1: Chemical composition of Ni-based superalloy Inconel 718

\begin{tabular}{|c|c|c|c|c|c|c|c|}
\hline \multicolumn{7}{|c|}{ Inconel 718 superalloy chemical composition, in mass } \\
fraction $(w / \%)$ \\
\hline $\mathrm{Ni}$ & $\mathrm{Cr}$ & $\mathrm{Nb}$ & $\mathrm{Mo}$ & $\mathrm{Ti}$ & $\mathrm{Al}$ & $\mathrm{Co}$ & $\mathrm{Si}$ \\
53.55 & 18.0 & 5.31 & 3.03 & 0.96 & 0.56 & 0.27 & 0.09 \\
\hline $\mathrm{Cu}$ & $\mathrm{Mn}$ & $\mathrm{C}$ & $\mathrm{Ta}$ & $\mathrm{P}$ & $\mathrm{B}$ & $\mathrm{S}$ & $\mathrm{Fe}$ \\
0.06 & 0.06 & 0.03 & 0.01 & 0.007 & 0.004 & 0.001 & Balance \\
\hline
\end{tabular}

\subsection{Porosity measurement of bond and top coats}

The structural changes of the as-sprayed specimens were examined after the porosity measurements. The porosity measurements were conducted using the Image J software package through the identification of the differences in the matrix and porosity colors. Five images of different regions of the coatings were taken at a 1000x magnification and the porosity value for each image was evaluated. The mean value of all the measurements was included in the experimental data.

\subsection{Measurements of the surface-roughness values of the bond and top coatings}

A SJ-310 Mitutoyo (Japan) test device was used for the surface-roughness measurements in accordance with DIN EN ISO 3274 standards. Each value was obtained after taking measurements in five different regions. The average value of these measurements was assumed as the surface-roughness value.

\subsection{Measurements of the hardness values of the sub- strate material, bond and top coat}

The measurements were conducted at five different depths from the coating surface. The hardness values of the coatings were measured using the Vickers indentation test with a Duramin microhardness tester (Qness, Q10A, Austria). The hardness measurements were taken via an application of a $0.1 \mathrm{~N}$ load for a period of $15 \mathrm{~s}$ for metallic bond coats. For the ceramic top coatings, a
$0.25 \mathrm{~N}$ load was applied for a period of $5 \mathrm{~s}$. Each test was repeated five times and the mean values were taken as the measurement results.

\subsection{Oxidation tests of TBC samples}

The produced TBC samples were cut into four pieces with a cutting tool in a laboratory environment. These specimens were subjected to oxidation tests in an openatmosphere furnace at $(900$ and 1000$){ }^{\circ} \mathrm{C}$ for $(8,24,50$ and 100) h.

\section{RESULTS AND DISCUSSION}

\subsection{Microstructural analysis of TBCs}

\subsubsection{Microstructural analysis of TBC samples before the oxidation test}

The average porosity percentages, surface roughness and hardness values of the as-sprayed TBCs are given in Table 2.

Table 2: Porosity, surface roughness and hardness of the coatings before the oxidation test

\begin{tabular}{|c|c|c|c|}
\hline TBCs & $\begin{array}{c}\text { Porosity } \\
(\%)\end{array}$ & $\begin{array}{c}\text { Surface } \\
\text { roughness } \\
\left(R_{\mathrm{a}}, \mu \mathrm{m}\right)\end{array}$ & $\begin{array}{c}\text { Hardness } \\
\text { value }(\mathrm{Hv})\end{array}$ \\
\hline YSZ & $7.1 \pm 0.55$ & $6.3 \pm 0.40$ & $805 \pm 35$ \\
\hline MSZ & $5.1 \pm 1.30$ & $5.7 \pm 0.35$ & $607 \pm 30$ \\
\hline
\end{tabular}

According to Table 2, some physical properties of TBCs can be compared with each other. The porosity level of the MSZ top coat is lower than that of YSZ, which is very important for the diffusion of oxygen over the bond coat. The surface-roughness values of TBCs are close to each other. The hardness of YSZ TBC is higher than that of MSZ TBC although the latter exhibits a lower porosity.

A SEM micrographs of the YSZ coating is given in Figure 2. Structural differences between the bond coat and YSZ can be observed. As seen in the figure, the metallic coating has a dense and non-porous structure. A SEM micrograph of the interface of the CoNiCrAlY bond coat and MSZ top coat is given in Figure 3. Both

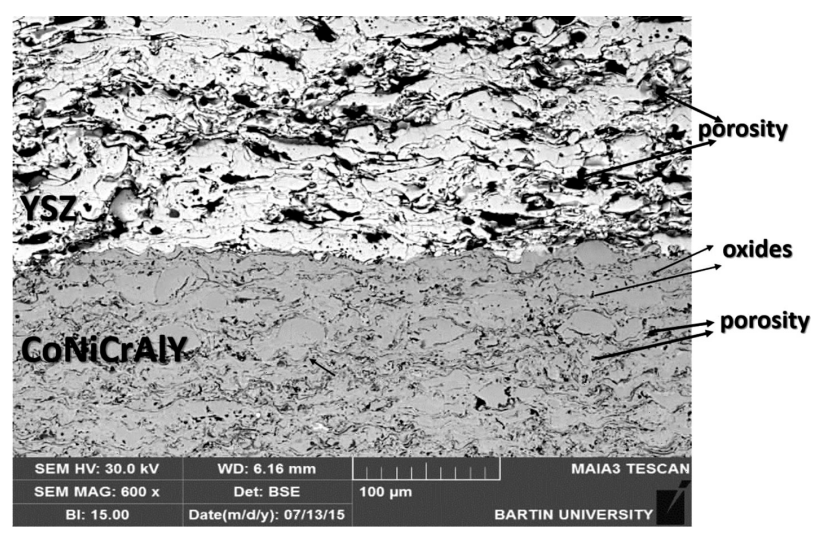

Figure 2: SEM image of the as-sprayed YSZ TBC 


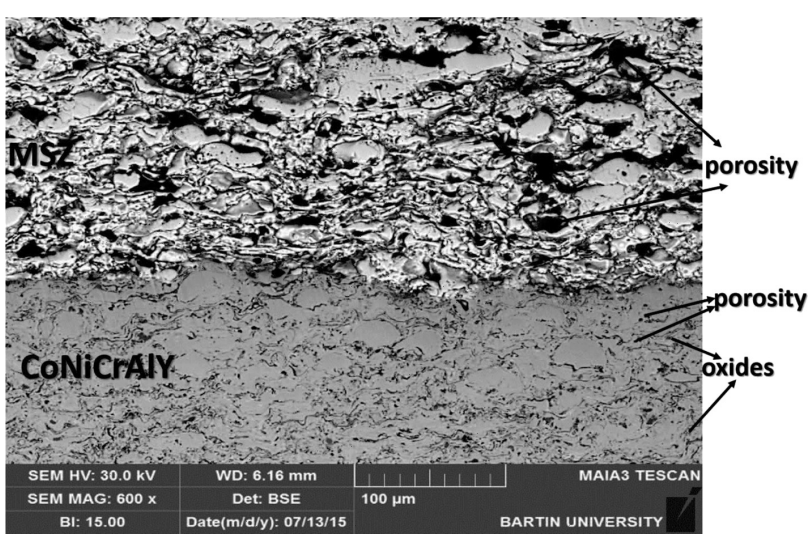

Figure 3: SEM image of the as-sprayed MSZ TBC

ceramic top-coating layers exhibit similar structures in terms of porosity and homogeneity.

\subsubsection{Microstructural analysis of TBC samples after the oxidation test}

3.1.2.1 Microstructures of TBCs after oxidation tests at $900{ }^{\circ} \mathrm{C}$ for $(8,24,50$ and 100$) h$

As seen in the SEM images from Figure 4, the TGO thickness is significantly low for YSZ TBC after an 8-h oxidation at $900{ }^{\circ} \mathrm{C}$. At the same temperature, the thickness of the TGO layer visibly increases with the increasing time. Higher periods of the exposure to temperature also increase the oxygen permeability of the structure, thus leading to oxidation as a result of a high oxygen content.

A uniform TGO growth occurred after the 8-h and 24-h oxidation periods, while an increase in the TGO thickness was observed after the 50 -h oxidation period. This is related to the aluminum depletion in the structure after $50 \mathrm{~h}$. Following this depletion, a formation of mixed oxides occurs. In Figures 4C and 4D, the blurred

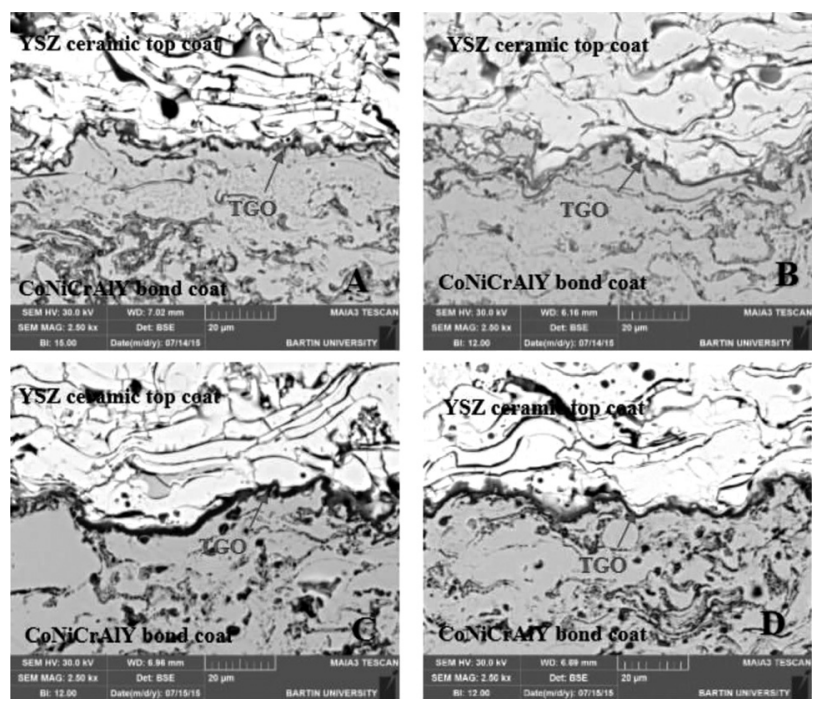

Figure 4: SEM images of APS-CoNiCrA1Y bond and APS-YSZ ceramic top coatings after the oxidation test at $900{ }^{\circ} \mathrm{C}$ : a) $8 \mathrm{~h}$, b) $24 \mathrm{~h}$, c) $50 \mathrm{~h}, \mathrm{~d}) 100 \mathrm{~h}$

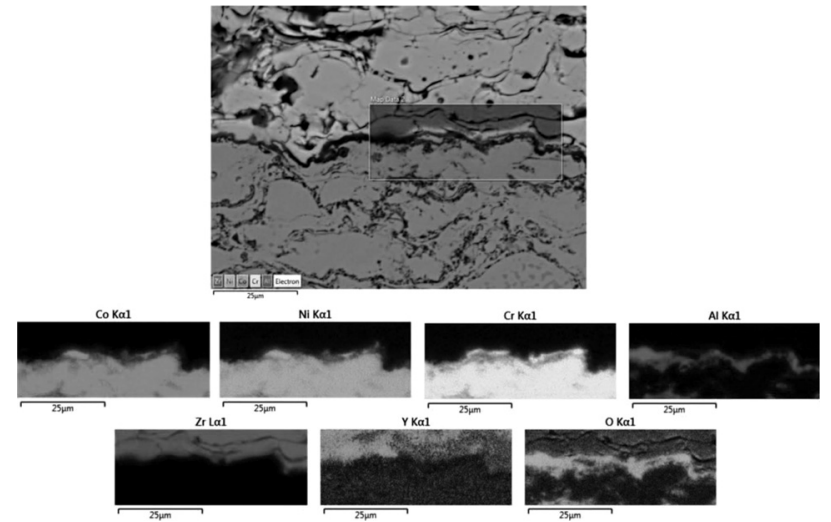

Figure 5: Elemental-analysis images of YSZ TBC after a 100-h oxidation at $900{ }^{\circ} \mathrm{C}$

gray areas in the upper regions of the TGO layer represent the mixed oxide formations. The elemental-analysis micrograph of the TBC system with the YSZ top ceramic coating after the 100 -h oxidation at $900{ }^{\circ} \mathrm{C}$ is given in Figure 5. In this figure, the $\mathrm{Al}_{2} \mathrm{O}_{3}$ formation is visible in the region where the TGO layer was formed. Regarding the elemental distribution, formations of mixed oxides and spinels such as $(\mathrm{Co}, \mathrm{Ni}) \mathrm{O}, \mathrm{Cr}_{2} \mathrm{O}_{3}$ and $(\mathrm{Co}, \mathrm{Ni})$ $(\mathrm{Cr}, \mathrm{Al})_{2} \mathrm{O}_{4}$ are indicated by the overlapping elemental colors. In the upper region of the TGO layer, dark-gray regions represent the mixed oxides.

2500× SEM micrographs of MSZ TBC after (8, 24, 50 and 100) h of oxidation at $900{ }^{\circ} \mathrm{C}$ are given in Figure 6. As indicated by the images, the TGO formation occurs in the form of a thin film layer after the 8 -h oxidation period. After $24 \mathrm{~h}$, the formation of mixed oxides is observed in the vicinity of the $\mathrm{Al}_{2} \mathrm{O}_{3}$ layer, indicated by a dark-gray color.

After 50-h and 100-h oxidation periods, an increased TGO thickness is observed in the structure. MSZ TBC exhibited a lower oxidation resistance than YSZ TBC.
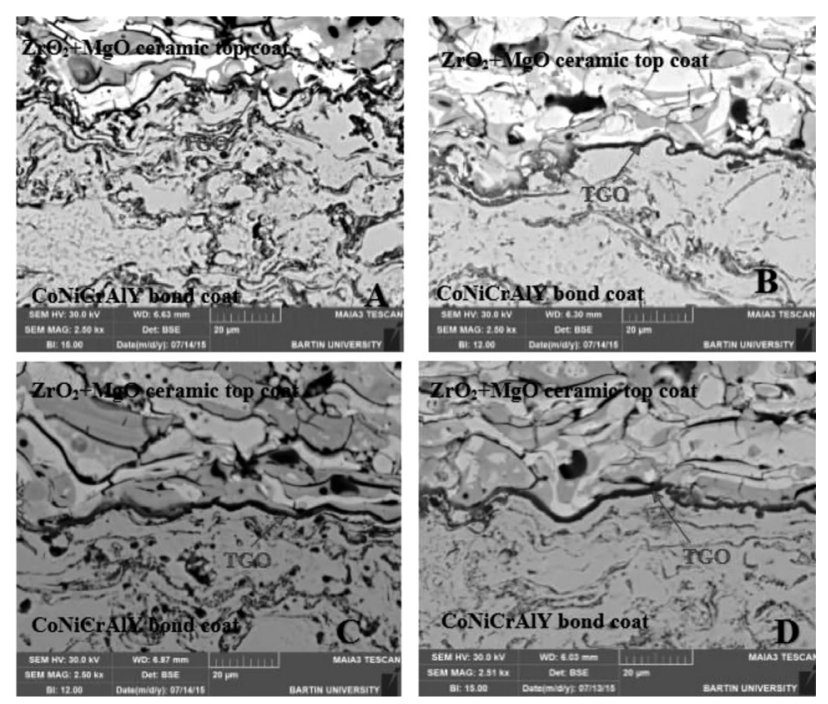

Figure 6: SEM images of MSZ TBC after the oxidation test at $900{ }^{\circ} \mathrm{C}$ : a) $8 \mathrm{~h}$, b) $24 \mathrm{~h}$, c) $50 \mathrm{~h}$, d) $100 \mathrm{~h}$ 


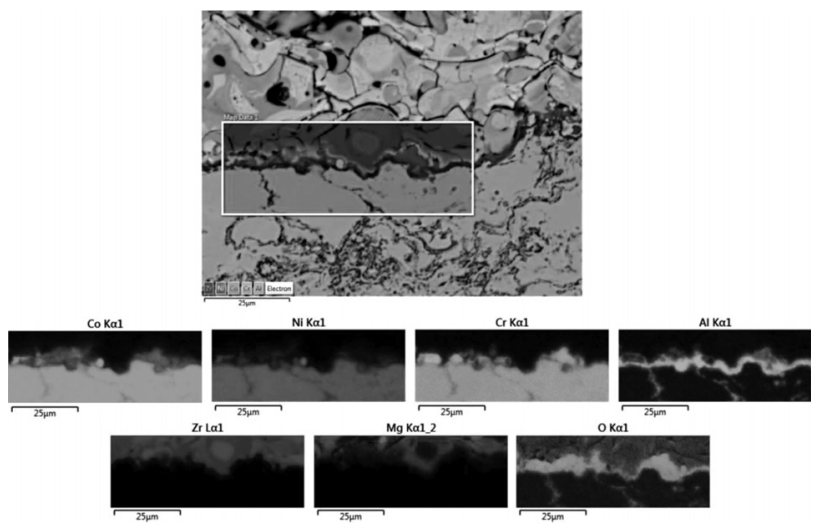

Figure 7: Elemental-analysis images of APS-MSZ ceramic top-coating layer after 100 -h oxidation at $900{ }^{\circ} \mathrm{C}$

Despite having a denser and more planar microstructure, it became even denser after the 100-h oxidation period. However, there was no significant difference between the TGO thicknesses when compared with the YSZ after 50and 100-h oxidation periods. The elemental-analysis micrograph of the MSZ TBC after the 100-h oxidation at $900{ }^{\circ} \mathrm{C}$ is given in Figure 7. In the elemental analysis, a large mixed-oxide content is visible in the upper region of the TGO structure, impairing the homogeneity of TGO. Especially the presence of cobalt and chromium with more dominant colors in the structure is an indication of the $\mathrm{Cr}_{2} \mathrm{O}_{3}$ and $(\mathrm{Co}) \mathrm{Al}_{2} \mathrm{O}_{4}$ spinel formations. The regions with aluminum and oxygen contents are clearly visible in this figure.

\subsubsection{Microstructures of TBC after oxidation tests at $1000{ }^{\circ} \mathrm{C}$ for $(8,24,50$ and 100) $h$}

The SEM micrographs of YSZ TBC after $(8,24,50$ and 100) h oxidation periods at $1000{ }^{\circ} \mathrm{C}$ are given in Figure 8. As seen in the micrographs, after $24 \mathrm{~h}$, mixedoxide formations are observed in the upper region of
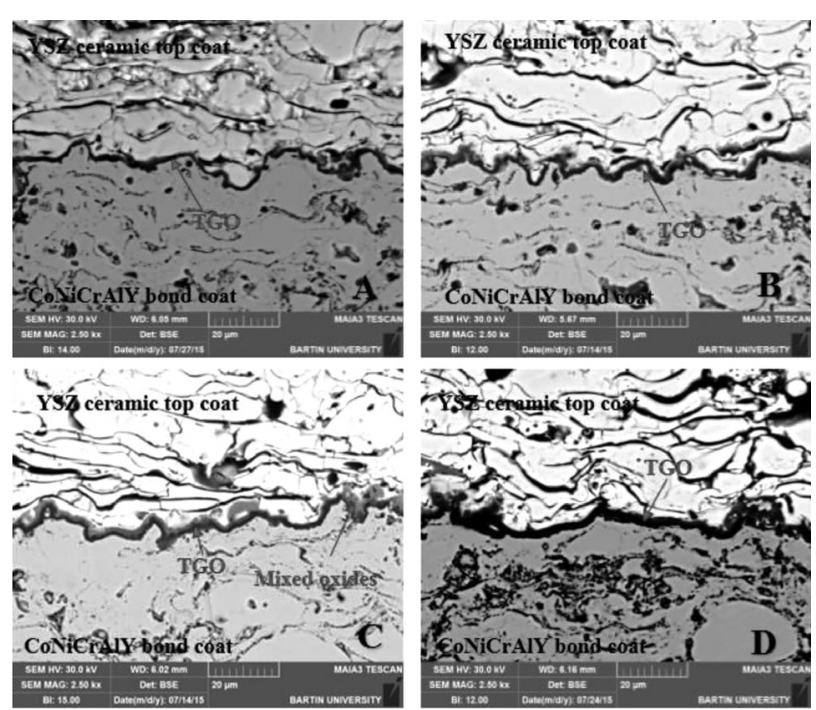

Figure 8: SEM images of YSZ TBC after the oxidation tests at $1000{ }^{\circ} \mathrm{C}$ : a) $8 \mathrm{~h}$, b) $24 \mathrm{~h}$, c) $50 \mathrm{~h}$, d) $100 \mathrm{~h}$

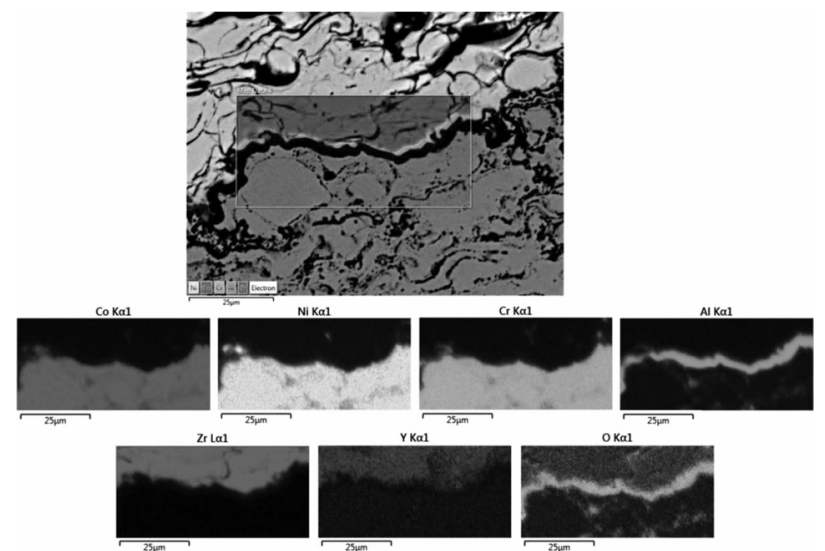

Figure 9: Elemental-analysis images of APS-YSZ ceramic-coating top layer after the 100 -h oxidation at $1000{ }^{\circ} \mathrm{C}$

TGO, indicated by a dark-gray color. An increase in the mixed-oxide formations was observed in the TGO layer after $50-\mathrm{h}$ and $100-\mathrm{h}$ oxidation periods. The TGO thickness increased with the increasing oxidation time.

Elemental-analysis micrographs of YSZ TBC after the 100 -h oxidation period at $1000{ }^{\circ} \mathrm{C}$ is given in Figure 9. As seen in the elemental analysis, there is a very low mixed-oxide formation and the dominant phase at the interface is $\mathrm{Al}_{2} \mathrm{O}_{3}$. However, internally oxidized areas were increased compared to the other oxidation periods.

The SEM micrographs of MSZ TBC after (8, 24, 50 and 100)-h oxidation periods at $1000{ }^{\circ} \mathrm{C}$ are given in Figure 10. The YSZ TBC subjected to the $1000{ }^{\circ} \mathrm{C}$ oxidation test was found to be more durable than the MSZ TBC. The presence of porosity and gaps as well as crack formations are visible in the microstructures of the TBCs. In the SEM images, a TGO formation is observed after the 8-h oxidation period. However, in this phase, a higher mixed-oxide content is exhibited compared to
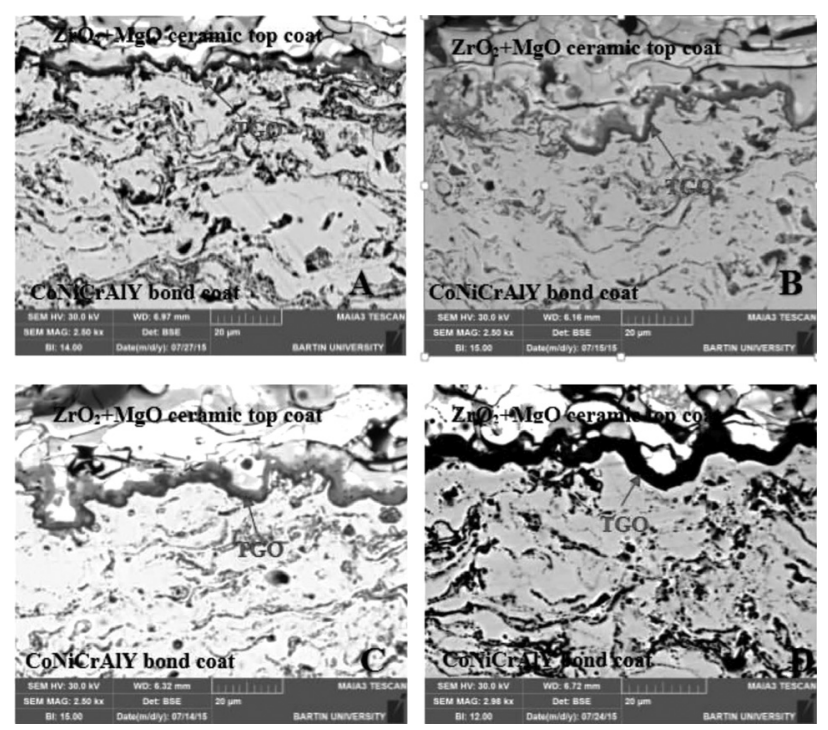

Figure 10: SEM images of MSZ TBC after the oxidation test at $100{ }^{\circ} \mathrm{C}$ : a) $8 \mathrm{~h}$, b) $24 \mathrm{~h}$, c) $50 \mathrm{~h}$, d) $100 \mathrm{~h}$ 


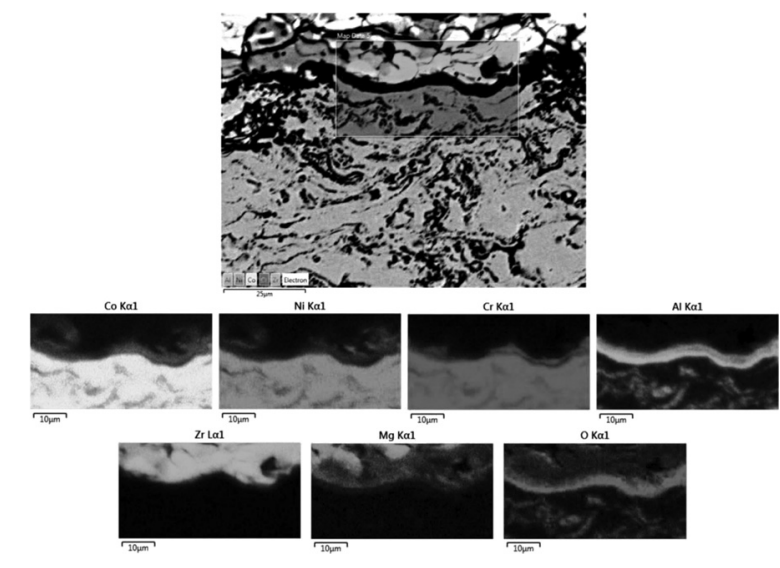

Figure 11: Elemental-analysis images of APS-MSZ ceramic top-coating layer after the 100 -h oxidation at $1000^{\circ} \mathrm{C}$

YSZ. After the 8-h and 24-h oxidation periods, a uniform TGO growth can also be seen, while an increase in the TGO thickness is observed after $50 \mathrm{~h}$. After the 50-h oxidation period, the MSZ exhibits a higher mixed-oxide content as compared to the YSZ top coat. A significant increase in the TGO-layer thickness is observed after the 100 -h oxidation period. After the 100 -h oxidation period at $1000{ }^{\circ} \mathrm{C}$, YSZ TBC outperforms MSZ TBC in terms of the TGO growth rate.

An elemental analysis of the TBC system with the MSZ ceramic top coating after the 100 -h oxidation at $1000{ }^{\circ} \mathrm{C}$ is given in Figure 11. Formations of alumina and mixed-oxide or spinel phases can be inferred from the overlapped colors. The homogeneity of the TGO layer decreased as compared to the samples subjected to the oxidation tests at $900{ }^{\circ} \mathrm{C}$ due to the increase in the temperature and internal oxidation. When Figures 9 and $\mathbf{1 1}$ are observed, mixed-oxide or spinel-phase formations are more visible according to the elemental distributions for the TGO layers. $\mathrm{Co}, \mathrm{Ni}$ and $\mathrm{Cr}$ traces can be observed above the $\mathrm{Al}_{2} \mathrm{O}_{3}$ layer.

\subsubsection{TGO growth behaviors of TBCs after isother-} mal-oxidation tests at 900 and $1000{ }^{\circ} \mathrm{C}$

The TGO-thickness measurements for the specimens subjected to the oxidation tests were carried out using

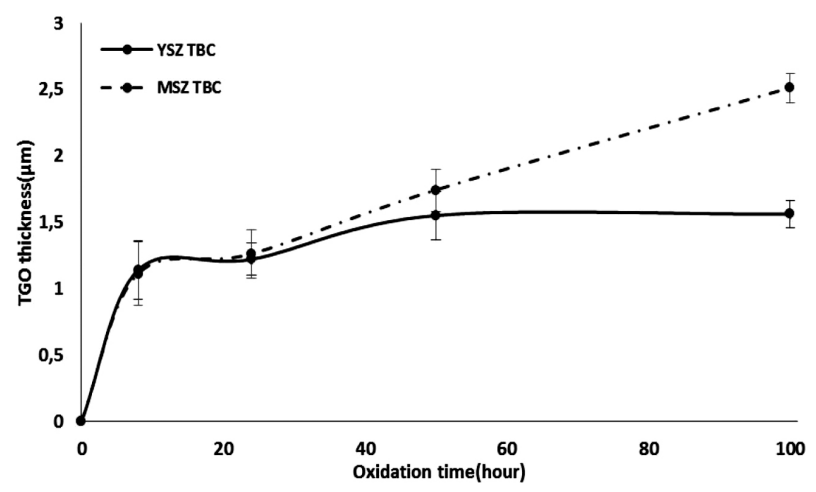

Figure 12: TGO-growth values for the TBCs with YSZ and MSZ ceramic top coatings after $(8,24,50$ and 100$) \mathrm{h}$ oxidation periods at $900{ }^{\circ} \mathrm{C}$

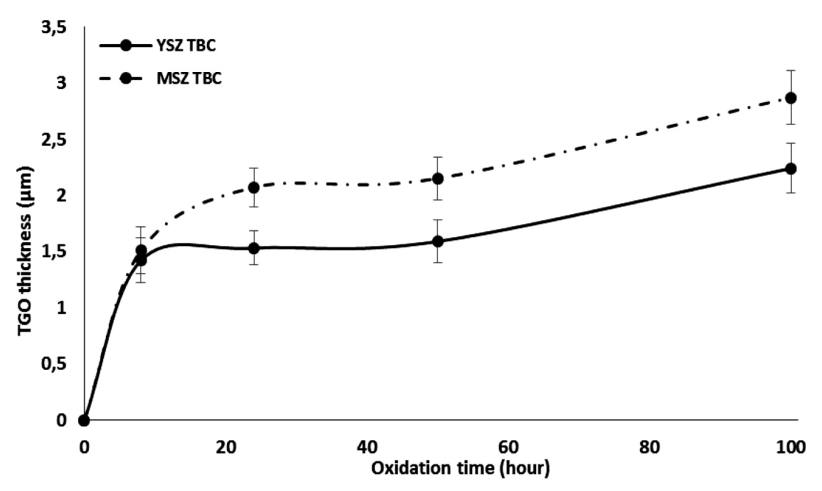

Figure 13: TGO-growth values for the TBCs with YSZ and MSZ ceramic top coatings after $(8,24,50$ and 100) h oxidation periods at $1000{ }^{\circ} \mathrm{C}$

the measurement function of the SEM device. SEM microstructure images were taken at a $2500 \times$ magnification and measurements were conducted along the TGO layer at specified intervals.

In terms of TGO-thickness measurements, the specimens with two different top coats exhibited almost identical TGO-growth behaviors. The TGO-layer thicknesses for the specimens with YSZ and MSZ ceramic top coating measured after $(8,24,50$ and 100) h oxidation periods at $900{ }^{\circ} \mathrm{C}$ and $1000{ }^{\circ} \mathrm{C}$ are given in Figures 12 and $\mathbf{1 3 .}$

As seen from the results, the TGO-thickness values for both TBCs are close to each other at the initial stages of oxidation. Afterwards, the TGO-thickness values for both coatings increased with the increasing time.

\subsection{XRD analyses of TBCs}

An investigation of the oxide phases present in the structures of both YSZ and MSZ coatings before and after the oxidation for 100 hours at $900{ }^{\circ} \mathrm{C}$ and $1000{ }^{\circ} \mathrm{C}$ was carried out with the XRD method.

The XRD results for the specimens with the YSZ and MSZ contents were obtained, for both coatings, before and after the oxidation tests (Figures 14 and 15). $\mathrm{ZrO}_{2}$ was completely stabilized in the tetragonal phase, but it included monoclinic and tetragonal phases after the oxidation tests.

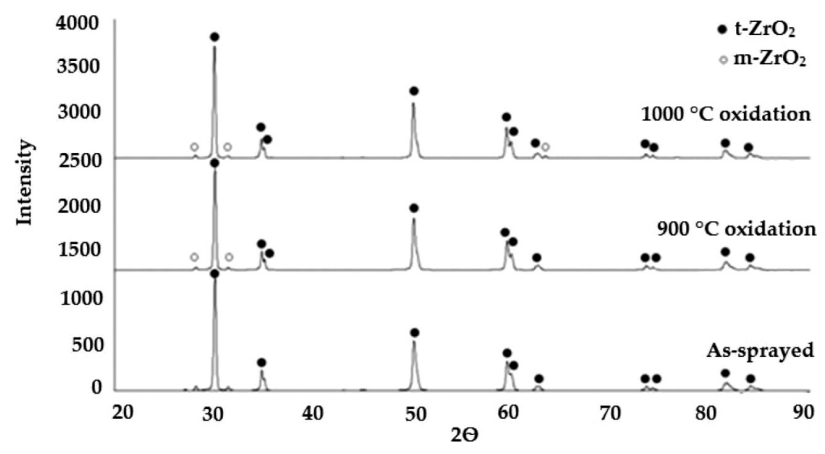

Figure 14: XRD results for YSZ top coating before and after the oxidation test 


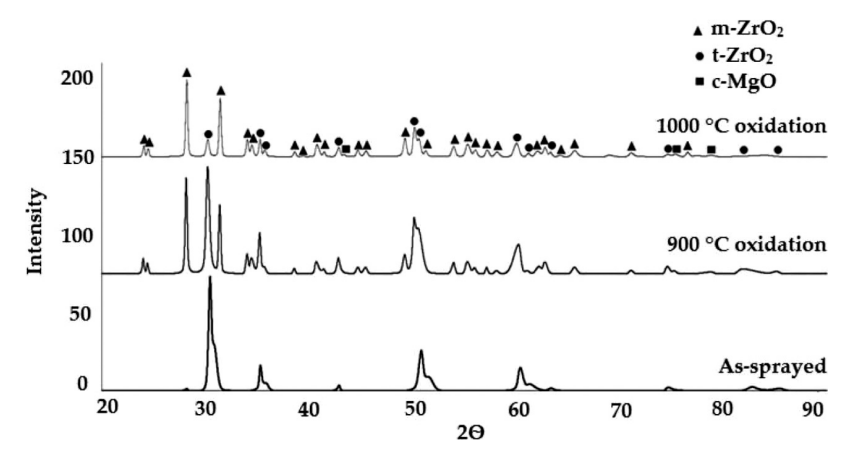

Figure 15: XRD results for MSZ top coating before and after the oxidation test

For the MSZ TBC, during the 900 - and $1000-{ }^{\circ} \mathrm{C}$ oxidation tests, a transition from the tetragonal to monoclinic phase occurred in the structure of the top coating, which was totally stabilized in the tetragonal phase with $\mathrm{MgO}$ before the oxidation. The overall results of the XRD analysis clearly indicate that a higher rate of phase transformation occurred on the MSZ top coating, compared to YSZ TBC.

\section{DISCUSSION}

In TBC systems, oxidation occurs due to the penetration of oxygen through the existing cracks and porosities in the top coating. The ionic conductivity of the top coat also allows progress of oxygen at high temperatures. The oxygen penetrating through the top coat reacts with the metallic bond coat and an oxidation occurs. ${ }^{19,20}$ After the oxidation of the bond coat, a TGO layer is formed at the interface. The $\mathrm{Y}$ and $\mathrm{Al}$ elements in the CoNiCrAlY bond coat oxidize first due to their high affinity to oxygen. Since the Y content is very small, only a very small amount of it is observed in the TGO layer, while the $\mathrm{Al}_{2} \mathrm{O}_{3}$ phase is predominant in the first stages of oxidation. Depending on the time, the existing Al-rich phases in the bond are consumed, and fast-growing mixed oxides and spinels form. As a result, the fast-growing oxides cause a high stress at the interface and a spallation of the top coat occurs. The TGO growth behaviors of the TBC systems with two different ceramic top coatings generally result in similar TGO-thickness values. . $^{51,21-27}$

Another different characteristic of top coatings is their high oxygen permeability. When $\mathrm{Zr}^{4+}$ and $\mathrm{Mg}^{2+}$ are displaced, two oxygen vacancies occur in the stabilization of $\mathrm{MgO}+\mathrm{ZrO}_{2}$. The formation of these vacancies accelerates the oxygen penetration from the top coat to the bond coat at high temperatures. ${ }^{28}$ However, the displacement of $\mathrm{Zr}^{4+}$ and $\mathrm{Y}^{3+}$ ions causes a formation of only one oxygen vacancy in YSZ TBC. Besides, YSZ exhibits a more porous structure as compared to MSZ TBC. The fact that YSZ is more porous causes more oxidation compared to MSZ. However, due to having a lower oxygen permeability as well as a higher phase stability, YSZ TBCs exhibit better resistance against high-temperature oxidation.

When the thermal-cycling behaviors of MSZ TBC at $1000{ }^{\circ} \mathrm{C}$ and $1050{ }^{\circ} \mathrm{C}$ were examined, rapid grain coarsening was observed. The sintering temperature for YSZ TBC was relatively higher than for MSZ. Khan et al. investigated the oxidation behavior of MSZ TBCs with a NiAl bond coat at different time periods at (750, 900 and 1000) ${ }^{\circ} \mathrm{C}$. They found that MSZ TBCs are not suitable for $1000^{\circ} \mathrm{C}$ and that it is more convenient to use them at temperatures of up to $750{ }^{\circ} \mathrm{C}$. Their bond-coat oxidation product mainly consists of nickel oxides. ${ }^{16}$ In the present study, MSZ TBC with the CoNiCrAlY bond coat can be durable up to $900{ }^{\circ} \mathrm{C}$ while YSZ TBC still preserves its stability at $1000{ }^{\circ} \mathrm{C}$. The most dominant phase is $\mathrm{Al}_{2} \mathrm{O}_{3}$ in the TGO layer due to the use of the CoNiCrAlY bond coat. Baig et al. studied the stress distribution in plasma-sprayed MSZ TBCs. Two types of the TBC system, a duplex one and a functionally graded one, were produced and their stress distributions in a range of $100-400{ }^{\circ} \mathrm{C}$ were investigate using finite-element modelling. ${ }^{17}$ The functionally graded MSZ TBCs exhibit better strength, overcoming the thermal-expansion mismatch. ${ }^{17}$ There is no other study about the oxidation of MSZ TBCs in the literature. However, there are many studies about the oxidation of YSZ TBCs under different temperatures and times. ${ }^{25-27,30}$

\section{CONCLUSIONS}

The conducted investigation was focused on the isothermal-oxidation behavior of the YSZ and MSZ ceramic top-coating systems. The main conclusions are listed below.

Porosity measurements of TBCs were conducted before the other experimental studies on the coatings. The obtained measurement results indicate that the YSZ coating exhibits higher porosity compared to the coatings with the MSZ content.

Based on the conducted analyses, the TGO growth of the MSZ coating was found to be higher than that of the YSZ ceramic top coating.

The TGO layer with the $\mathrm{Al}_{2} \mathrm{O}_{3}$ content exhibited a uniform structure at the initial stages of oxidation. With the increasing oxidation period, depletion of $\mathrm{Al}$ in the coating structure occurred at different temperatures. In addition, formation of mixed oxides such as $\mathrm{NiO}, \mathrm{Cr}_{2} \mathrm{O}_{3}$ and $\mathrm{CoO}$ was observed due to the presence of $\mathrm{Co}, \mathrm{Ni}$ and $\mathrm{Cr}$ in the coating.

The phase analyses conducted on the ceramic top coatings prior to the oxidation indicated that the YSZ ceramic top coating included $\mathrm{t}-\mathrm{ZrO}_{2}$ and the $\mathrm{MSZ}$ coating included the $\mathrm{t}-\mathrm{ZrO}_{2}, \mathrm{~m}-\mathrm{ZrO}_{2}$ and $\mathrm{c}-\mathrm{MgO}$ phase structures after $1000{ }^{\circ} \mathrm{C}$ and 100 -h oxidation, which means that the MSZ coating was negatively affected by this oxidation condition. Because of the phase transfor- 
mation, volumetric changes in the coating structure caused cracks.

For lower-temperature applications $\left(<900^{\circ} \mathrm{C}\right)$, the use of MSZ TBC may be more suitable than YSZ TBC due to its lower production cost.

\section{REFERENCES}

${ }^{1}$ S. R. Dhineshkumar, M. Duraiselvam, S. Natarajan, S. S. Panwar, T. Jena, M. A. Khan, Enhancement of strain tolerance of functionally graded LaTi2A19O19 thermal barrier coating through ultra-short pulse based laser texturing, Surf. Coat. Tech., 304 (2016), 263-271, doi:10.1016/j.surfcoat.2016.07.018

${ }^{2}$ G. Pujol, F. Ansart, J.-P. Bonino, A. Malié, S. Hamadi, Step-by-step investigation of degradation mechanisms induced by CMAS attack on YSZ materials for TBC applications, Surf. Coat. Tech., 237 (2013), 71-78, doi:10.1016/j.surfcoat.2013.08.055

${ }^{3}$ J. J. Tang, Y. Bai, J. C. Zhang, K. Liu, X. Y. Liu, P. Zhang, Y. Wang, L. Zhang, G. Y. Liang, Y. Gao, J. F. Yang, Microstructural design and oxidation resistance of CoNiCrAlY alloy coatings in thermal barrier coating system, J. Alloys Compd., 688 (2016), 729-741, doi:10.1016/j.jallcom.2016.07.018

${ }^{4}$ Z. Khan, S. Fida, F. Nisar, N. Alam, Investigation of Intergranular Corrosion in 2nd stage gas turbine blades of an aircraft engine, Eng. Fail. Anal., 68 (2016), 197-209, doi:10.1016/j.engfailanal.2016.05. 033

${ }^{5}$ Z. Xu, L. He, Y. Zhao, R. Mu, S. He, X. Cao, Composition, structure evolution and cyclic oxidation behavior of $\mathrm{La} 2(\mathrm{Zr} 0.7 \mathrm{Ce} 0.3) 2 \mathrm{O} 7$ EB-PVD TBCs, J. Alloys Compd., 491 (2010), 729-736, doi:10.1016/j.jallcom.2009.11.053

${ }^{6}$ Z. Xu, Z. Wang, G. Huang, R. Mu, L. He, Thermal cycling behavior of EB-PVD TBCs on CVD platinum modified aluminide coatings, J. Alloys Compd., 637 (2015), 226-233, doi:10.1016/j.jallcom.2015. 02.177

${ }^{7}$ L. Yang, T. T. Yang, Y. C. Zhou, Y. G. Wei, R. T. Wu, N. G. Wang, Acoustic emission monitoring and damage mode discrimination of APS thermal barrier coatings under high temperature CMAS corrosion, Surf. Coat. Tech., 304 (2016), 272-282, doi:10.1016/j.surfcoat. 2016.06.080

${ }^{8}$ V. Crespo, I. G. Cano, S. Dosta, J. M. Guilemany, The influence of feedstock powders on the CGS deposition efficiency of bond coats for TBCs, J. Alloys Compd., 622 (2015), 394-401, doi:10.1016/ j.jallcom.2014.09.216

${ }^{9}$ W. Fan, Y. Bai, Review of suspension and solution precursor plasma sprayed thermal barrier coatings, Ceram. Int., 42 (2016), 14299-14312, doi:10.1016/j.ceramint.2016.06.063

${ }^{10}$ A. C. Karaoglanli, E. Altuncu, I. Ozdemir, A. Turk, F. Ustel, Structure and durability evaluation of YSZ+A12O3 composite TBCs with APS and HVOF bond coats under thermal cycling conditions, Surf. Coat. Tech., 205 (2011), S369-S373, doi:10.1016/j.surfcoat.2011. 04.081

${ }^{11}$ A. Keyvani, M. Saremi, M. Heydarzadeh Sohi, Z. Valefi, M. Yeganeh, A. Kobayashi, Microstructural stability of nanostructured YSZ-alumina composite TBC compared to conventional YSZ coatings by means of oxidation and hot corrosion tests, J. Alloys Compd., 600 (2014), 151-158, doi:10.1016/j.jallcom.2014.02.004

${ }^{12}$ A. Keyvani, M. Saremi, M. H. Sohi, Oxidation resistance of YSZ-alumina composites compared to normal YSZ TBC coatings at
$1100{ }^{\circ} \mathrm{C}$, J. Alloys Compd., 509 (2011), 8370-8377, doi:10.1016/ j.jallcom.2011.05.029

${ }^{13}$ M. J. Lance, K. A. Unocic, J. A. Haynes, B. A. Pint, APS TBC performance on directionally-solidified superalloy substrates with HVOF NiCoCrAlYHfSi bond coats, Surf. Coat. Tech., 284 (2015), 9-13, doi:10.1016/j.surfcoat.2015.08.067

${ }^{14}$ H. E. Evans, Oxidation failure of TBC systems: An assessment of mechanisms, Surf. Coat. Tech., 206 (2011), 1512-1521, doi:10.1016/j.surfcoat.2011.05.053

${ }^{15}$ X. Fang, G. Zhang, X. Feng, Performance of TBCs system due to the different thicknesses of top ceramic layer, Ceram. Int., 41 (2015), 2840-2846, doi:10.1016/j.ceramint.2014.10.105

${ }^{16}$ A. N. Khan, I. N. Qureshi, Microstructural evaluation of $\mathrm{ZrO} 2-\mathrm{MgO}$ coatings, J. Mater. Process. Tech., 209 (2009), 488-496, doi:10.1016/ j.jmatprotec.2008.02.032

${ }^{17}$ M. N. Baig, F. A. Khalid, F. N. Khan, K. Rehman, Properties and residual stress distribution of plasma sprayed magnesia stabilized zirconia thermal barrier coatings, Ceram. Int., 40 (2014), 4853-4868, doi:10.1016/j.ceramint.2013.09.035

${ }^{18}$ W. Ma, H. Dong, Ceramic thermal barrier coating materials, Thermal Barrier Coatings, Woodhead Publishing, 2011, 25-52

${ }^{19}$ A. C. Fox, T. W. Clyne, Oxygen transport by gas permeation through the zirconia layer in plasma sprayed thermal barrier coatings, Surf. Coat. Tech., 184 (2004), 311-321, doi:10.1016/j.surfcoat.2003. 10.018

${ }^{20}$ I. O. Golosnoy, S. Paul, T. W. Clyne, Modelling of gas permeation through ceramic coatings produced by thermal spraying, Acta Mater, 56 (2008), 874-883, doi:10.1016/j.actamat.2007.09.045

${ }^{21}$ R. Kitazawa, M. Tanaka, Y. Kagawa, Y. F. Liu, Damage evolution of TBC system under in-phase thermo-mechanical tests, Materials Science and Engineering: B, 173 (2010), 130-134, doi:10.1016/ j.mseb.2009.12.022

${ }^{22}$ W. J. Quadakkers, V. Shemet, D. Sebold, R. Anton, E. Wessel, L. Singheiser, Oxidation characteristics of a platinized MCrAlY bond coat for TBC systems during cyclic oxidation at $1000{ }^{\circ} \mathrm{C}$, Surf. Coat. Tech., 199 (2005), 77-82, doi:10.1016/j.surfcoat.2004.11.038

${ }^{23}$ L. Wang, J. S. Yang, J. X. Ni, C. G. Liu, X. H. Zhong, F. Shao, H. Y. Zhao, S. Y. Tao, Y. Wang, Influence of cracks in APS-TBCs on stress around TGO during thermal cycling: A numerical simulation study, Surf. Coat. Tech., 285 (2016), 98-112, doi:10.1016/j.surfcoat.2015. 11.036

${ }^{24}$ L. Zhou, S. Mukherjee, K. Huang, Y. W. Park, Y. Sohn, Failure characteristics and mechanisms of EB-PVD TBCs with Pt-modified NiAl bond coats, Materials Science and Engineering: A, 637 (2015), 98-106, doi:10.1016/j.msea.2015.03.120

${ }^{25}$ A. C. Karaoglanli, K. M. Doleker, B. Demirel, A. Turk, R. Varol, Effect of shot peening on the oxidation behavior of thermal barrier coatings, Appl. Surf. Sci., 354 (2015), 314-322, doi:10.1016/ j.apsusc.2015.06.113

${ }^{26}$ K. M. Doleker, A. C. Karaoglanli, Comparison of oxidation behavior of YSZ and Gd2Zr2O7 thermal barrier coatings (TBCs), Surf. Coat. Tech., 318 (2017), 198-207, doi:10.1016/j.surfcoat.2016.12.078

${ }^{27}$ K. M. Doleker, A. C. Karaoglanli, Comparison of Oxidation Behavior of Shot-Peened Plasma Spray Coatings with Cold Gas Dynamic Spray Coatings, Oxid. Met., 88 (2017) 1-2, 121-132, doi: $10.1007 / \mathrm{s} 1108$

${ }^{28}$ X. Q. Cao, R. Vassen, D. Stoever, Ceramic materials for thermal barrier coatings, J. Eur. Ceram. Soc., 24 (2004), 1-10, doi:10.1016/ S0955-2219(03)00129-8 